\title{
WYRAZY ZAPOŻYCZONE Z JĘZYKA POLSKIEGO W SŁOWNIKU GWAR SMOLEŃSKICH WŁODZIMIERZA DOBROWOLSKIEGO
}

\author{
POLISH LOANWORDS \\ IN DICTIONARY OF SMOLENSK DIALECTS \\ OF VLADIMIR DOBROVOLSKY
}

\author{
MARIAN WÓJTOWICZ
}

\begin{abstract}
AвStRAct. The analysis comprises a stock of 414 Polish loanwords selected from the dictionary of Smolensk dialects. In the article the following problems are discussed: the stock of loanwords, periods and the process of the borrowing. Most of the words were borrowed as a result of direct language contacts. Some of the words were borrowed through Belarussian. The majority of them were borrowed in the 17th, 19th and at the beginning of the 20th century.
\end{abstract}

Keywords: Polish loanwords, Smolensk dialects, Dobrovolsky's dictionary, Russian dialect lexicography

Marian Wójtowicz, Uniwersytet im. Adama Mickiewicza w Poznaniu, Poznań - Polska, maw@amu.edu.pl

ORCID ID: 0000-0002-5657-7787

Wzrost zainteresowania kulturą i językiem ludowym, który uwidocznił się już w połowie XIX wieku, sprawił, że rosyjska leksykografia gwarowa osiągnęła znaczny poziom rozwoju. Różnorodny materiał leksykalny pochodzący w większości z obszaru poszczególnych guberni europejskiej części Rosji stał się podstawą wielu słowników gwarowych, które zaczęły ukazywać się pod koniec XIX wieku jako odrębne opracowania lub w postaci dodatków do prac dialektologicznych. Ówczesna leksykografia wychodziła z założenia, że fakty językowe powinno się ujmować łącznie z etnograficznymi i że słownictwo gwarowe należy ukazywać na tle życia i zwyczajów ludowych. Pierwszym słownikiem, w którym założenie to znalazło pełne odbicie, było dzieło Aleksandra O. Podwysockiego, obejmujące słownictwo gwarowe całej guberni archangielskiej [Подвысоцкий 1885]. W krótkim czasie stało się ono wzorem dla autorów kolejnych słowników. Do tego grona należy Włodzimierz Dobrowolski (1856-1929), rosyjski etnograf i znawca folkloru, autor słownika gwar smoleńskich [Добровольский]. Słownik 
opiera się na opublikowanym przez Dobrowolskiego czterotomowym zbiorze smoleńskich materiałów etnograficznych, z których wydobył on słownictwo gwarowe i uzupełnił wyrazami wybranymi z prac innych autorów [Сороколетов, Кузнецова 1987: 64]. Wartość słownika ocenił jego pierwszy recenzent Ewfimij F. Karski, który odnotował, że chociaż materiał w nim zebrany pochodzi ze stosunkowo niewielkiego obszaru, to jednak jest wystarczająco pełny i wyróżnia się bogatą treścią [Карский 1962: 442]. Pomimo wielu niedociągnięć leksykograficznych dotyczących nieuregulowanej postaci zapisu wyrazów hasłowych (zapisy na wpół fonetyczne, wg Karskiego „в полуфонетическом виде"), naruszeń porządku alfabetycznego, różnych sposobów podawania znaczenia wyrazu, słownik Dobrowolskiego do czasu ukazania się nowoczesnego obszernego słownika gwarowego był jedynym zbiorem słownictwa gwar smoleńskich [ССГ].

Ze słownika Dobrowolskiego ekscerpowano 414 wyrazów, które w różnych okresach zostały zapożyczone z języka polskiego do gwar smoleńskich ${ }^{1}$. Do najstarszych należą wyrazy zapożyczone do XV wieku. Grupa ta liczy 19 wyrazów (5\%), wśród których najwięcej jest rzeczowników, np.: Вoũm, жовнер, махина, маятность 'posiadłość', пани, пригода 'przygoda; nieszczęśliwy wypadek', рада, размова, хуста $\|$ хвуста, цебир, цкода. Jest też kilka czasowników: мовить, мусить, муровать, позычить, пророковать, przymiotnik пышный i przysłówek досыть.

Z XVI wieku pochodzi 60 wyrazów (15\%). Przeważają tu rzeczowniki nazywające rozmaite przedmioty codziennego użytku, nazwy odzieży, produktów przeznaczonych do spożycia: Вага' drąg, dźwignia', жупан, жур, кармазон 'rodzaj sukna', келих, ланцуг, цъыбуля, шкатула; nazwy pomieszczeń, budowli, instytucji: камора, кляштор, сенат; nazwy оsób: блазен, господыня, лотр, пан, персона, хлопец, швагер, швагерка; nazwy pojęć abstrakcyjnych: година, жарт, намова 'oszczerstwo, obmowa', плюгавство, послуга, проба, регула, роскошь 'bogactwo, obfitość', смова 'zmówiny'. Nieliczne są czasowniki: бачuть, будовать, кохаться, меть, личить, радить, рушать, икодить, przymiotniki: заможный, набожныи 'uczciwy, sumienny', особливыи, певный, прикрый, jest też jeden przysłówek - зимно.

Liczną grupę stanowią zapożyczenia XVII wieku. Zawiera ona 97 wyrazów (23\%), w większości rzeczowników, będących nazwami przedmiotów używanych w życiu codziennym, sprzętów domowych, naczyń, np.: гарнеu, гонт, кахля, клямка, коло 'koło młyńskie', постромка, склянка, скрыня, шахва 'szafa', катанка, панчоха, demin. панчошка, саян 'wełniana suknia, pasiasta

${ }^{1}$ Okres zapożyczenia wyrazu ustalano na podstawie słowników historycznych, etymologicznych, słowników i wykazów zapożyczeń oraz opracowań słownictwa zapożyczonego. Wyrazy przytacza się w postaci podanej w słowniku. 
spódnica', сукенка, табакерка, хустка, шата 'bogate odzienie'; nazwy budynków, pomieszczeń i urządzeń wokół domu: ганкu 'stopnie na ganku', ганок, каплициа, лазня, фортка, шинок; nazwy osób: бестия 'hultaj, szelma', возак, забойца, кат, мушкатер, плюгавеи, фррант, фурман, иляхтянка. Jest tutaj także kilkanaście rzeczowników abstrakcyjnych: бруд, варта, грозьба, забойство, залицанье 'zaloty', забобоны, заручины, казанъе, кочт, мичба, мова, оказия, покора, поправа, праци, ращея 'pouczenie'. Znajdują się w tej grupie zapożyczone czasowniki: блазновать, вандровать 'włóczyć się', жартовать, нема, немаш, ошукивать, пановать, пиловать $\|$ пилувать, пильновать пильнувать, працовать, псовывать\|псувать, робить, чекать, шинковать 'sprzedawać, handlować', цукать. Jest też parę przymiotników: латвый, належный, пекельный, плюгавый, смачный, стислый 'skąpy', por. stpol. ścisty 'skąpy, skrzętny', шкодливый, щирый oraz przysłówków: навылёт, оподаль, треба.

Znaczny spadek liczby zapożyczeń następuje w XVIII wieku. W porównaniu z poprzednim okresem jest to grupa niemal o połowę mniejsza, licząca 43 wyrazy $(10 \%)$. Są to przede wszystkim rzeczowniki oznaczające różne przedmioty, ozdoby, części odzieży: андарак 'spódnica', карпетка, перлы, mорба; nazwy potraw i produktów spożywczych: клёцки, разынки, скиба 'kromka'; wyrazy z zakresu życia towarzyskiego, społecznego, religijnego: кантычки, кирмаж\|кирмаш, мина 'wyraz twarzy', манерка 'miarka wódki', особливость, поспех, презент, танок 'korowód, taniec', турбация; nazwy osób: бляхарь, швачка, nazwy osiedli: вёска, фольворок. Należą tu również czasowniki: готовать, муштровать, намалёвать, потурбовать 'zaniepokoić', расквасить, смаковать, сховать\|схувать, тримать\|трымать, школить 'uczyć, karać', przymiotniki: брудный, мизерный, несмачный oraz przysłówki: аккурат, досконально, квит \|къита 'koniec, zakończona sprawa', неможно.

Najliczniej w słowniku są reprezentowane wyrazy zapożyczone w XIX i na początku XX wieku. W skład tej grupy wchodzi 195 wyrazów $(47 \%)$. Zwraca uwagę różnica ilościowa pomiędzy tą grupą i zapożyczeniami XVIII wieku. Zbliżony wynik uzyskano w badaniach nad zapożyczeniami w słownikach gwar rosyjskich połowy XIX w., w których zapożyczenia XVIII-wieczne stanowiły $10,8 \%$, natomiast wyrazy przejęte w XIX wieku - 42,6\% ogółu analizowanych polonizmów [Wójtowicz 2012: 374-375]. Polonizacja Smoleńszczyzny w XVII w., która pozostawiła swój ślad w słownictwie gwarowym, nie uległa całkowitemu zahamowaniu w XVIII wieku pomimo carskich restrykcji administracyjnych [Расторгуев 1960: 189-191]. Wydaje się, że wpływ polski znalazł swoje odbicie w postaci dużej liczby zapożyczeń odnotowanych dopiero w słownikach XIX w. Wśród zapożyczeń XIX - początku XX wieku dominują rzeczowniki (98 wyrazów) i czasowniki (66 wyrazów). Rzeczowniki stanowią bardzo zróżnicowaną znaczeniowo grupę. Są to nazwy rozmaitych sprzętów domowych, narzędzi, urządzeń, 
pojazdów, obuwia, drobnych przedmiotów: бизун, гузик, кавалэк, колыска, кошик, ляк 'lak', обиуги, обиужки, окравок, пантуфильки, пральник, распалка, рина 'koryto, młynówka', тайстра, фрурманка, халупа, ц̧ацһа, цзацка 'zabawka dziecięca', u̧beuนк; nazwy napojów, produktów spożywczych: akabuтая \|кавитая, мазурка 'ciasto wielkanocne', папироса, помпуика 'placuszek; pulchna kobieta'; dość liczne są nazwy osób: барнадын 'rosły mężczyzпа', выхуванец, выхуванка, господарь, зух, жачик, кеп 'głupiec', кепа 'głupia', ковалёвна, коханка, лахудра 'niechlujna kobieta', лойдак, лярва 'rozpustnica', махар 'szachraj', махлер 'oszust', научитель, обшарпанеи, паненка, радиа, распустник 'urwis', фармазон 'człowiek dziwacznie odziany, spryciarz, wolnomyśliciel'; mniejsze grupy tworzą nazwy związane z pracą i różnymi zajęciami: блонье, целизна 'grunt nietknięty pługiem', позычка, пляма, решma; nazwy części ciała, chorób: дуna, пэйсы, пранец, пранцы 'wrzody syfilityczne', цъыики 'piersi, sutki'; nazwy zwierząt, owadów, ptaków, ryb: кaßкa, ментуз, прусак, слонка, шпак, щупак; wyrazy związane z uroczystościami, obrzędowością, wierzeniami: пекельник 'diabeł', покута 'żałoba, ubiór żałobny; skrucha', покутник, подарунок, шлюба. Są w tej grupie rzeczowniki abstrakcyjne: бзик 'dziwactwo', гариы ' pijatyka', грубизна, згуба, ляк 'liczba, ilość' - zapis zapewne niedokładny, por. pol. lik 'duża liczba' i wyrażenie bez liku 'bardzo dużo'; маёнтык, крадеж\|крадёж, моруда 'zwłoka', мюбость, митренга, митренженье, опанованье, оседлость, отведины, отмова, перевага, придуха 'przyducha, śnięcie ryb', nyдлo 'chybiony strzał; błąd', paзbaza, pauнъе, распуста, ратунок, ремус 'strofowanie, oremus', стиск 'ciasnota'.

Do zapożyczonych w tym okresie czasowników należą, np.: выгарнуmъ, сгарнуть, огорнуть 'оkорас́, okryć', отгорнуть, вытворять, гандлевать, гарнуться 'przytulać się, lgnąć', деньковать, зниважить, квапиться 'łasić się na cudze dobro, łaknąć', кировать, конать, кпить, коштоваться 'częstować się', ладнеть, латать, лупежить, лыкать, мацоваться 'pracować z wysiłkiem', мизернеть, морудить, митренжить, нараить, нарадить, порадить, подраить, пораить, раить, напрацоваться, наробить, переробить, нашкодить, обтинать, обтять, расцинать, обшарпать, одрапать, опановать, опековаться, отаксовать, отштурхивать, перешукивать, плюгавить, поважать, порятовать, послизнуться, сланяться 'włóсzус́ się', смажить, спотыкать, стратить, турбуваться 'kłócić się, spierać', улякнуться, шанувать.

W tej grupie zapożyczeń jest też kilkanaście przymiotników: каханый, кbaпливыи 'zawistny, zazdrosny', крухавый, латаный, незграбный, нелекливый, оседлый, особистый, осхлый, пропадлый, разважный, снадный 'odpowiedni, stosowny', трефный oraz parę przysłówków: за ненацку (pod hasłem ненаик 'coś nieoczekiwanego'), właściwie зе ненацку, pol. znienacka, маркотно, поти$x y$, напочатку, преч 'precz; przedtem', обертасом w wyrażeniu быть обертасом 'szybko powrócić', раптом. 
Należy jeszcze wspomnieć o rzadkich przykładach, których znaczenie słownikowe dokładnie określa ich chronologię. Są to wyrazy nовстанеu, i дидки 1. mn. 'zaostrzone kije używane do zwalczania polskich powstańców 1863 r.'. Wpływy polskie pozostawiły ślad w sferze życia codziennego tego okresu, o czym świadczą tytuły i wyrażenia grzecznościowe: мосnане - forma wołacza rzeczownika мосnан 'mości pan', bащumь 'waszeć; człowiek wyniosły', добрыденъ, добрывечир, добраночъ.

W analizie zapożyczeń nie sposób pominąć wyrazów polskich będących dziedzictwem epoki prasłowiańskiej lub mających odpowiedniki w językach zachodniosłowiańskich. Pewna ich część ma zasięg geograficzny ograniczony do obszaru zachodnich gwar rosyjskich, niekiedy południoworosyjskich. Mogą one być wynikiem kontaktów językowych międzysłowiańskich, zwłaszcza jeśli uwzględni się silne wpływy polskie na słownictwo języków wschodniosłowiańskich i późną datację większości zapożyczeń w rosyjskim. Na przykład prasł. *l'ubostb 'upodobanie, dobrotliwość, życzliwość, ukochanie, przyjemność' [ЭССЯ 15: 178], stpol. lubość ‘przyjemność, łaskawość, życzliwość, rozkosz' od 1418 r. [SS IV: 70-71], chor./serb. dawn. dial. syбocm 'dobroć, miłość'; wyraz rozpowszechniony w językach zachodniosłowiańskich, $\mathrm{w}$ ros. tylko $\mathrm{w}$ gwarach smoleńskich - ^юбость 'przyjemne uczucie wywołane zdziwieniem lub zachwytem', w sąsiednich gwarach briańskich ^юбость 'dobre przyjacielskie stosunki' [СРНГ 17: 239], por. wsp. brus. ^юбасиь 'miłość', dial. ^юбосиъ 'łaska, życzliwość'. Prasł. *konati 'kończyć, doprowadzać do końca' [ЭССЯ 10: 181-182], stpol. konać 'czynić, działać' od XIV w., 'umierać' od XV w. [Boryś 247], strus. конати 'doprowadzać do końca, niszczyć (pokonać)’ od 1635 r. [CРЯ 7: 269]; w dialektach ros. duże zróżnicowanie znaczeń: конать zamęczać, zadręczać, gnębić; dusić, uciskać; błagać, wypraszać; uciekać' [СРНГ 10: 181], ale tylko w gwarach smoleńskich i kurskich конать 'umierać', por. brus. конаць 'ts.' [Носович 244]. Vasmer [Фасмер II: 307] sugeruje pożyczkę z polskiego. Prasł. *smažiti 'powodować wysychanie w wysokiej temperaturze; przypiekać, prażyć', pol. smażyć 'prażyć, piec produkt żywnościowy; palić, przypiekać' od XV w. [Boryś 562]; w ros. wyłącznie w gwarach, смажить 'prażyć, piec' smol., psk., płd., zach., смажиться tylko w gwarach smoleńskich [СРНГ 38: 338], por. brus. смажицъ 'piec na tłuszczu' [Носович 593]. Pogląd o zapożyczeniu tego rodzaju wyrazów z polskiego do gwar rosyjskich nie jest odosobniony. Na przykład Aleksander Brückner uważał, że wyraz godzina '1/24 część doby', w gwarach smoleńskich година 'ts.', prasł. * godina, „od nas [jest] i na Rusi i na Litwie" [Brückner 148]. Według Maxa Vasmera [Фасмер II: 356] кoxamı 'kochać' zach., smol., prasł. *kochati (sę), tylko w gwarach smoleńskich кохаться 'kochać się, lubić się' [СРНГ 15: 120], jest zapożyczeniem z polskiego. 
Włodzimierz Dobrowolski zamieścił w słowniku 126 wyrazów (30,4\%), które do zasobu gwarowego nie należą, lecz są częścią słownictwa języka ogólnego. Sporo takich wyrazów rejestruje siedemnastotomowy słownik współczesnego rosyjskiego języka literackiego [ССРЛЯ]. Nр.: банкет, бляшка, забава, мешанина, муровать, особа, пышный, расквасить, сенат, табакерка, танеи, фррант, фундамент itp. Część z nich to wyrazy przestarzałe, пр.: камора, карпетка, кат, кошт, оказия, покора, пановать, послуга, презент, фармазон, фурман, щвачка. Niektóre polonizmy należą dziś do słownictwa potocznego, nр.: плюгавый, смачный, смаковать, фортка, школить, хлопеи, ц̧аияа lub pospolitego, nр.: вытоворять, латать, мордовать, обшарпать, окуляры, плюгавеи, торба, шкодить, шкодливый itр.

Większość wyrazów polskich została zapożyczona do gwar smoleńskich w wyniku kontaktu bezpośredniego. Należy jednak wziąć pod uwagę to, że proces zapożyczania odbywał się $\mathrm{w}$ warunkach silnego oddziaływania języka białoruskiego, ale pośrednictwa tego języka nie można w wielu wypadkach stwierdzić. Za pośrednictwem białoruskim zapożyczono wyrazy, np.: акавитая |кавитая 'wódka', z fleksją przymiotnikową, pol. okowita od XVII w. [Brückner 377], brus. акавитка \|кавитка [Носович 4], przest. акавіта 'ts'; будзъян |буцян 'bocian', brus. буияя [Носович 40]; ганки 'stopnie na ganku', brus. ганки 'ts.' [Носович 109]; кавмерь\|каумерь 'kołnierz', brus. ковнер 'ts.' [Носович 240]; кишенья 'kieszen', pol. kieszeń od XVII w., kieszenia w XVI w. [Boryś 230], strus. кишень 'ts.', 1589 r. [СРЯ 7: 144], brus. кишеня 'ts.' [Носович 285]; кайстра 'woreczek, torba, torebka', wariant rzeczownika maũ стра, mpaũcma 'ts.', pol. tajstra 'torba', także kaistra [Brückner 564], brus. кайстра 'ts.'. Niewykluczone, że pod wpływem białoruskim nastąpiła zmiana semantyki czasownika кbапиться 'łasić się na coś, na cudze dobro', pol. kwapić się 'zabierać się do czego z ochotą, raźnie' od XV w. [Boryś 277], stpol. kwapić się 'spieszyć się', kwapić k sobie 'wabić kogo ku sobie' [Reczek 177, SS III: 474], brus. кBanuนьц̧а 'z zawiścią patrzyć na co, pragnąc z tego skorzystać', квапливый 'zawistny' [Носович 232], wsp. brus. квапіцица ‘być chciwym'.

Należy podkreślić, że przy zapożyczaniu rzeczowniki z reguły zachowują znaczenie i kategorie gramatyczne swoich polskich prototypów. Niekiedy jednak rodzaj gramatyczny ulega zmianie. Wyraz ślub 'zawarcie związku małżeńskiego', dawn. szlub, uzyskał rodzaj żeński шлюба 'ts.' zapewne pod wpływem rodzaju rosyjskich rzeczowników свадьба, женитьба, por. brus. шлюб 'ts.' [Носович 713]. Rodzaj gramatyczny zmieniły zapożyczenia: крама z pol. kram pod wpływem ros. лавка 'sklep', мазурка z pol. mazurek 'rodzaj ciasta wielkanocnego' - ros. (сладкая сдобная) булка; nапера z pol. papier ros. бумага, por. brus. i ukr. папера 'ts.'. Wyraz илюба wskazuje, że zmiana rodzaju wymienionych rzeczowników była wynikiem wpływu rosyjskiego, a nie pośrednictwa białoruskiego. 
Podstawową grupę polonizmów w słowniku Dobrowolskiego stanowią wyrazy, które wzbogaciły słownictwo gwarowe. Zawiera ona 288 zapożyczeń, wśród których można wyróżnić dwie warstwy: wyrazy używane wyłącznie w gwarach smoleńskich i wyrazy będące zarazem częścią zasobu leksykalnego innych gwar rosyjskich. Pierwszą warstwę tworzy 137 wyrazów (48\%), głównie rzeczowników i czasowników. Są to rzeczowniki, np.: бзик, варта, вёска, година, господарь, жачик, забойиа, згуба, зух, личба, лотр, мешанеи, митренга, намова, научитель, отмова, пекельник, перевага, развага, размова, решта, рина, смова, тлум, турбация, извечик, шиагер itp., oraz czasowniki, nр.: блазновать, вандровать, готовать, деньковать, кохаться, кпить, ладнеть, лупежить, лыкать, намовлять, одрапать, прибудовать, сквапить, скваснеть, скривдить, сланяться itp. Należą tu także przymiotniki, np.: брудный, квапливый, крухавый, латвый, належный, певный, прикрый, пропадлый, разважный, снадный itp. W drugiej warstwie zapożyczeń najliczniejsze są wyrazy właściwe gwarom smoleńskim i południoworosyjskim, a w szczególności briańskim, kurskim i orłowskim. Odnotowano 122 wyrazy (42\%) wspólne dla wymienionych gwar, np. rzeczowniki: блонье, бруд, гузик, казанъе, катанка, клямка, падлина, панчоха, подарунок, покута, порада, поспех, пригода, придуxa, pапуха, распалка, цебир, шата itp., oraz czasowniki, np.: бачить, битать, дюбнуть, конать, меть, мусить, пильновать, працовать, псовать, спотыкать, стратить, хилить, чекать, шанувать itp. Jest też kilka przymiotników, np.: заможный, каханый, незграбный, стислый. Znacznie mniej jest zapożyczeń polskich wspólnych gwarom smoleńskim i środkoworosyjskim, głównie pskowskim, w mniejszym stopniu twerskim. Słownik notuje jedynie 24 te same wyrazy (8\%), a wśród nich rzeczowniki, np.: блазен, грозьба, дупа, жарт, жур, кирмаш, обшарпанеи, распуста, сzasowniki, nр.: опановать, отштурхивать, послизнться oraz przymiotnik пекельный. Niewiele jest $\mathrm{w}$ tej warstwie wyrazów używanych w gwarach smoleńskich i zarazem znanych gwarom północnorosyjskim (ok. 2\%), nowogrodzkim, kostromskim, jarosławskim, sporadycznych $\mathrm{w}$ gwarach archangielskich, np.: кавалок, крадеж(ъ)\| крадёж(ъ), мова, мовить, наробить.

$\mathrm{Z}$ analizy zebranego materiału można wyprowadzić następujące wnioski. Wielka liczba polonizmów w słowniku Włodzimierza Dobrowolskiego jest świadectwem silnego wpływu języka polskiego na słownictwo rosyjskie na obszarze Smoleńszczyzny. Część zapożyczeń (30,4\%) należy do słownictwa języka ogólnego, pozostałe wyrazy $(69,6 \%)$ wzbogaciły słownictwo gwarowe. Porównanie liczby polonizmów ze słownika Dobrowolskiego z zasobem wyrazów zapożyczonych z polskiego w innych gwarach rosyjskich pozwala stwierdzić, że pod względem liczby zapożyczeń gwary smoleńskie zajmują pierwsze miejsce (288 wyrazów), w niewielkim stopniu wyprzedzając gwary pskowskie (273 wyrazy) i zachodnie gwary briańskie (266 wyrazów). Zapo- 
życzenia polskie zaczynają napływać szerszym strumieniem na teren Smoleńszczyzny w XVI wieku. W wieku XVII ich napływ staje się jeszcze silniejszy, a w XVIII wieku ulega spowolnieniu. Najliczniejsze są wyrazy zapożyczone w XIX i na początku XX wieku, stanowiące niemal połowę ogólnej liczby badanych wyrazów. Większość wyrazów polskich została zapożyczona w wyniku kontaktu bezpośredniego z językiem rosyjskim. Pewną część wyrazów przejęto za pośrednictwem języka białoruskiego. Wśród zapożyczeń najliczniejsze są rzeczowniki - 236 wyrazów (57\%) i czasowniki - 118 wyrazów (29\%). Znacznie mniej jest przymiotników - 33 wyrazy (8\%) i przysłówków - 18 wyrazów (4\%). Odnotowano kilka partykuł: бадай, нихай oraz юж - także $w$ funkcji przysłówka i zaimek якuй. Zapożyczenia dotyczą rozmaitych dziedzin życia ludności wiejskiej. Są to głównie wyrazy z zakresu kultury materialnej, nazwy przedmiotów codziennego użytku, sprzętów domowych, narzędzi, pomieszczeń, nazwy odzieży, obuwia, tkanin, produktów spożywczych, napojów (39\%). Sporą grupę tworzą nazwy osób, części ciała, nazwy zwierząt, owadów, płazów, ryb (29\%). Bardzo liczne są abstracta (32\%). Wśród czasowników najwięcej jest wyrazów nazywających czynności związane z zachowaniem człowieka, współżyciem społecznym, okazywaniem pomocy, komunikowaniem się, stanem posiadania (48\%), a następnie czasowników wyrażających czynności z zakresu prac domowych i gospodarczych (24\%). Mniejsze grupy stanowią czasowniki dotyczące przemieszczania się, ruchu, przyrządzania posiłków (16\%) oraz określające doznania wzrokowe, smakowe, dotykowe, czynności umysłowe i stany psychiczne (12\%).

Słownik Dobrowolskiego rejestruje słownictwo sprzed ponad stu lat i ukazuje ówczesny zbiór wyrazów polskiego pochodzenia. Do pełniejszego poznania zasobu zapożyczeń i poszerzenia dotychczasowej wiedzy w tym zakresie mogłyby się niewątpliwie przyczynić badania nad polonizmami we współczesnych gwarach smoleńskich.

\section{Wykaz skrótów}

$\begin{array}{ll}\text { brus. } & \text { - białoruski } \\ \text { chor./serb. } & \text { - chorwacki i serbski } \\ \text { dawn. } & \text { - dawny } \\ \text { demin. } & \text { - deminutivum } \\ \text { dial. } & \text { - dialekt, dialektyczny } \\ \text { płd. } & \text { - południowy } \\ \text { pol. } & \text { - polski } \\ \text { przest. } & \text { - przestarzały } \\ \text { psk. } & \text { - pskowski }\end{array}$

$\begin{array}{ll}\text { prasł. } & \text { - prasłowiański } \\ \text { ros. } & \text { - rosyjski } \\ \text { smol. } & \text { - smoleński } \\ \text { stpol. } & \text { - staropolski } \\ \text { strus. } & \text { - staroruski } \\ \text { ts. } & - \text { to samo } \\ \text { ukr. } & \text { - ukraiński } \\ \text { wsp. } & - \text { współczesny } \\ \text { zach. } & - \text { zachodni }\end{array}$




\section{Bibliografia}

Добровольский - Добровольский В. Н. 1914. Смоленский областной словарь, Смоленск: Типография П. А. Силина.

Карский Е. Ф. 1962. Труды по белорусскому и другим славянским языкам, Москва: Изд. AH СССР.

Носович - Носович И. И. 1870. Словарь белорусского наречия, Санкт-Петербург: Изд. Отделения русского языка и словесности имп. АН.

Подвысоцкий А. О. 1885. Словарь областного архангельского наречия в его бытовом и этнографическом применении, Санкт-Петербург: Изд. II Отделения имп. АН.

Расторгуев П. А. 1960. Говоры на территории Смоленщины, Москва: Изд. АН СССР.

Сороколетов Ф. П., Кузнецова О. Д. 1982. Очерки по русской диалектной лексикографии, Ленинград: Наука.

СРНГ - Филин Ф. П., Сороколетов Ф. П. (red.) 1965-2010. Словарь русских народных говоров, вып. 1-43, Москва-Ленинград-Санкт-Петербург: Наука.

СРЯ - Бархударов С. Г., Богатова Г. А., Крысько В. Б. (red.) 1975-2011. Словарь русского языка XI-XVII въ., вып. 1-29, Москва: Наука.

ССГ - Иванова А. И., Бояринова Л. 3. (red.) 1974-2005. Словарь смоленских говоров, вып. 1-11, Смоленск: Смоленский государственный педагогический университет.

ССРЛЯ - Чернышев В. И. (red.) 1950-1965. Словарь современного русского литературного языка, t. I-XVII, Москва-Ленинград: Изд. АН СССР, Наука.

Фасмер М. 1964-1973. Этимологический словарь русского языка. Перевод с нем. и дополнения О. Н. Трубачева, t. I-IV. Москва: Прогресс.

ЭССЯ - Трубачев О. Н. (red.) 1974-2005. Этимологический словарь славянских языков. Праславянский лексический фонд, вып. 1-31, Москва: Наука.

Boryś - Boryś W. 2005. Stownik etymologiczny języka polskiego, Kraków: Wydawnictwo Literackie.

Brückner - Brückner A. 1970. Stownik etymologiczny języka polskiego, Warszawa: Wiedza Powszechna.

Reczek - Reczek S. 1968. Podręczny słownik dawnej polszczyzny, Wrocław: Zakład Narodowy im. Ossolińskich.

SS - Urbańczyk S. (red.). 1953-2003. Stownik staropolski, t. I-XI, Warszawa-Wrocław-Kraków: Instytut Języka Polskiego PAN.

Wójtowicz M. 2012. Zapożyczenia z języka polskiego w słownikach gwar rosyjskich połowy XIX wieku, [w:] D. Paśko-Koneczniak (red.) Wspótczesne badania nad kultura, literatura i językiem rosyjskim, Toruń: Wydawnictwo Naukowe Uniwersytetu Mikołaja Kopernika, s. 371-386. 
